\title{
Developing Therapeutic Alternatives for Treatment-resistant Bipolar Depression: The Role of Riluzole
}

\author{
Tedavi Dirençli Bipolar Depresyonda Gelişen Tedavi Seçenekleri: Riluzol
}

\author{
(D) Sidar Çöpür ${ }^{1}$, (1) Mazlum Çöpür ${ }^{2}$ \\ ${ }^{1}$ Koç University Faculty of Medicine, Department of Internal Diseases, İstanbul, Turkey \\ ${ }^{2}$ Arel University Faculty of Medicine, Department of Psychology, İstanbul, Turkey
}

\section{Dear Editor,}

Bipolar disorder (BD) refers to a set of conditions characterised by depressive, manic, or hypomanic episodes. This chronic psychiatric disease affects $2.4 \%$ of the adult population in the United States of America (0.6\% BD-I, 0.4\% BD-II and $1.4 \%$ sub-threshold BD). ${ }^{1}$ The treatment primarily involves administration of mood-stabiliser medications such as lithium and valproate. Additional options include psychotherapy and the prescription of atypical anti-psychotics. ${ }^{2}$ However, the rise in the number of treatment-resistant bipolar depression cases has prompted the investigation of N-methyl-D-aspartate (NMDA) receptor antagonists. This interest has been sparked by reports on abnormalities related to glutamatergic neurotransmission in studies involving animal and human subjects. ${ }^{3,4}$ Such defects include the presence of elevated levels of glutamate in the plasma and cerebrospinal fluid, alterations in the NMDA-receptor binding, defects in the genetic expression in areas associated with long-term potentiation and diminished expression of certain metabotropic glutamate receptors (GluR2 and GluR3). ${ }^{3}$ Promising preliminary results obtained upon ketamine administration have encouraged the investigation of riluzole, a potent NMDA antagonist approved by the Food and Drug Administration, for the treatment of amyotrophic lateral sclerosis through delayed neuronal degeneration. ${ }^{5,6}$

In a double-blind, placebo-controlled, randomised controlled trial (RCT) involving 19 subjects diagnosed with BD (age: 1870 years), the patients were randomised into either placebo or 50-200 mg riluzole group for an 8-week observation period. The riluzole group showed statistically significant lower anxiety scores than the placebo group, as assessed by the Hamilton Rating scale for anxiety, and no difference in the depression scores, as assessed by the Montgomery-Åsberg Depression
Rating scale (MADRS) and Hamilton Rating scale for depression. A total of 10 participants (5 in the placebo group and 5 in the riluzole group) did not complete the 8 -week trial course (3 placebo group patients withdrew from the participation owing to the following reasons: one due to deterioration of depressive status, one due to severe headache and another due to influenza infection). ${ }^{7}$ Although RCT did not favour riluzole therapy for bipolar depression, we believe that our study results were challenged by the limitations of small sample size, participant withdrawals and the relatively short period of intervention. Another study on 14 bipolar cases in which the patients received 50-200 mg riluzole for 8 weeks in case of MADRS score $\geq 20$ after 4 weeks of treatment with lithium also demonstrated the beneficial effects of riluzole for bipolar depression treatment. No manic or hypomanic episodes were recorded during the course of riluzole therapy. ${ }^{8}$ In general, no intolerable adverse effects were observed. ${ }^{7,8}$ In addition, a past study on 19 adult patients with non-bipolar treatment-resistant major depression (MADRS score 220) revealed significant improvements with riluzole treatment (mean dosage $=169 \mathrm{mg}$ /day) for 6 weeks. ${ }^{9}$ However, the efficiency of riluzole was limited in ketamineresistant major depression cases and hence the combination therapy of riluzole with ketamine was deemed to be less effective than the use of ketamine alone. ${ }^{10,11}$

NMDA antagonists have been proven to exert beneficial effects in treatment-resistant bipolar depression cases with valid pathophysiological background; however, relevant studies in the literature are limited owing to the small sample size and the short intervention and follow-up durations. Hence, there is a need for large-scale and comprehensive RCTs to investigate the efficacy and safety of riluzole treatment in patients with bipolar depression. Moreover, physicians should be aware of such developing areas of psychiatric research which are likely to

Address for Correspondence/Yazıșma Adresi: Sidar Çöpür MD, Koç University Faculty of Medicine, Department of Internal Diseases,

Istanbul, Turkey

Phone: +90 5076033585 E-mail: scopur14@ku.edu.tr ORCID: orcid.org/0000-0003-0190-2746

Received/Geliș Tarihi: 06.03.2020 Accepted/Kabul Tarihi: 13.07.2020

${ }^{\circ}$ Copyright 2020 by the Turkish Association for child and Adolescent Psychiatry / Turkish Journal of Child and Adolescent Mental Health. published by Galenos Publishing House. 
influence clinical practise in the coming years.

Keywords: Bipolar disorder, riluzole, depression, N-methyl-D-aspartate receptor, glutamate

Anahtar Kelimeler: Bipolar bozukluk, riluzol, depresyon, N-metil-Daspartat reseptörü, glutamat

\section{Ethics}

Peer-review: Externally and internally peer-reviewed.

\section{Authorship Contributions}

Concept: S.Ç., M.Ç., Design: S.Ç., M.Ç., Data Collection or Processing: S.Ç., Analysis or Interpretation: S.Ç., M.Ç., Literature Search: S.Ç., Writing: S.Ç., M.Ç.

Conflict of Interest: No conflict of interest was declared by the authors.

Financial Disclosure: The authors declared that this study received no financial support.

\section{References}

1. Merikangas KR, Jin R, He JP, Kessler RC, Lee S, Sampson NA, Viana MC, Andrade LH, Hu C, Karam EG, Maria Ladea M, Medina-Mora ME, Ono Y, Posada-Villa J, Sagar R, Wells JE, Zahari Zarkov Z. Prevalence and correlates of bipolar spectrum disorder in the world mental health survey initiative. Arch Gen Psychiatry. 2011;68:241251.

2. McCormick U, Murray B, McNew B. Diagnosis and treatment of patients with bipolar disorder: A review for advanced practice nurses. J Am Assoc Nurse Pract. 2015;27:530-542.

3. Machado-Vieira R, Ibrahim L, Henter ID, Zarate Jr CA. Novel glutamatergic agents for major depressive disorder and bipolar disorder. Pharmacol Biochem Behav. 2012;100:678-687.
4. Thompson SM, Kallarackal AJ, Kvarta MD, Van Dyke AM, LeGates TA, Cai X. An excitatory synapse hypothesis of depression. Trends Neurosci. 2015;38:279-294.

5. Newport DJ, Carpenter LL, McDonald WM, Potash JB, Tohen M, Nemeroff CB. APA Council of Research Task Force on Novel Biomarkers and Treatments. Ketamine and Other NMDA Antagonists: Early Clinical Trials and Possible Mechanisms in Depression. Am J Psychiatry. 2015;172:950-966.

6. Bobo WV, Vande Voort JL, Croarkin PE, Leung JG, Tye SJ, Frye MA. Ketamine for treatment-resistant unipolar and bipolar major depression: critical review and implications for clinical practice. Depress Anxiety. 2016;33:698-710.

7. Park LT, Lener MS, Hopkins M, Iadorola N, Machado-Vieira R, Ballard E, Nugent A, Zarate Jr CA. A Double-Blind, Placebo-Controlled, Pilot Study of Riluzole Monotherapy for Acute Bipolar Depression. J Clin Psychopharmacol. 2017;37:355-358.

8. Zarate CA, Jr., Quiroz JA, Singh JB, Denicoff KD, De Jesus G, Luckenbaugh DA, Charney S, Manji HK. An open-label trial of the glutamate-modulating agent riluzole in combination with lithium for the treatment of bipolar depression. Biol Psychiatry. 2005;57:430432.

9. Zarate CA Jr, Payne JL, Quiroz J, Sporn J, Denicoff KK, Luckenbaugh DA, Charney S, Manji HK. An open-label trial of riluzole in patients with treatment-resistant major depression. Am J Psychiatry. 2004;161:171-174.

10. Ibrahim L, Diazgranados N, Franco-Chaves J, Brutsche N, Henter ID, Kronstein P, Moaddel R, Wainer I, Luckenbaugh DA, Manji HK, Zarate Jr CA. Course of improvement in depressive symptoms to a single intravenous infusion of ketamine vs add-on riluzole: results from a 4-week, double-blind, placebo-controlled study. Neuropsychopharmacology. 2012;37:1526-1533.

11. Niciu MJ, Luckenbaugh DA, Ionescu DF, Richards EM, Vande Voort JL, Ballard ED, Brutsche NE, Furey ML, Zarate Jr CA. Riluzole likely lacks antidepressant efficacy in ketamine non-responders. J Psychiatr Res. 2014;58:197-199. 